\title{
A material-performance-based database for FRC and RC elements under shear loading
}

\author{
Estefanía Cuenca • Antonio Conforti • Fausto Minelli • Giovanni A. Plizzari • \\ Juan Navarro Gregori · Pedro Serna
}

Received: 20 June 2017 / Accepted: 29 December 2017/Published online: 12 January 2018

\begin{abstract}
The shear strength of elements reinforced by fibres is predicted by Codes using formulations generally developed from a limited set of test results. In fact, only few of available test results are combined with a material mechanical characterization, allowing to evaluate and compare the different performances of Fibre Reinforced Concretes (FRC). To address this problem, a material-performance-based shear database for FRC elements and their related reference samples in Reinforced Concrete (RC, with and without web reinforcement) is presented herein, merging the experiences carried out in the last decade at the University of Brescia and at the Universitat Politècnica de València. The database is composed by 171 specimens: 93 in FRC and 78 in RC with or without web reinforcement. For FRC elements, the postcracking resistance $\left(f_{\mathrm{R}, 1}\right.$ and $\left.f_{\mathrm{R}, 3}\right)$ is also given according to EN 14651 standard. The evaluation of
\end{abstract}

E. Cuenca $(\bowtie)$

Universitat Politècnica de València, Valencia, Spain

e-mail: estefania.cuenca@polimi.it

Present Address:

E. Cuenca

DICA - Department of Civil and Environmental Engineering,

Politecnico di Milano, Milan, Italy

A. Conforti - F. Minelli - G. A. Plizzari

DICATAM - Department of Civil, Environmental,

Architectural Engineering and Mathematics, University of

Brescia, Brescia, Italy

e-mail: antonio.conforti@unibs.it the shear database was also carried out, discussing the influence of the different factors affecting the shear strength both in FRC and RC samples. Finally, the two formulations suggested by Model Code 2010 for FRC elements are compared against the database results in order to shed new light on code requirements.

Keywords Steel fibres - Macro-synthetic fibres . Fibre reinforced concrete $\cdot$ Shear $\cdot$ Shear database . Model code 2010

\section{List of symbols}

$A_{\mathrm{p}} \quad$ Area of prestressing steel

$A_{\mathrm{s}} \quad$ Longitudinal reinforcement area

$b_{\mathrm{w}} \quad$ Web width

CMOD Crack mouth opening displacement

F. Minelli

e-mail: fausto.minelli@unibs.it

G. A. Plizzari

e-mail: giovanni.plizzari@unibs.it

J. Navarro Gregori · P. Serna

ICITECH - Concrete Science and Technology Institute, Universitat Politècnica de València, Valencia, Spain e-mail: juanagre@cst.upv.es

P. Serna

e-mail: pserna@cst.upv.es 


\begin{tabular}{|c|c|}
\hline$d$ & Effective depth \\
\hline$d_{\mathrm{g}}$ & Maximum aggregate size \\
\hline$E_{\mathrm{s}}$ & $\begin{array}{l}\text { Modulus of elasticity of longitudinal } \\
\text { reinforcement }\end{array}$ \\
\hline$E_{\mathrm{p}}$ & Modulus of elasticity of prestressing steel \\
\hline$f_{\mathrm{c}}$ & Cylinder compressive concrete strength \\
\hline$f_{\mathrm{ck}}$ & $\begin{array}{l}\text { Characteristic value of cylinder } \\
\text { compressive concrete strength }\end{array}$ \\
\hline$f_{\mathrm{ct}}$ & Mean value of tensile concrete strength \\
\hline$f_{\mathrm{Ftu}}$ & $\begin{array}{l}\text { Ultimate residual strength according to } \\
\text { Model Code } 2010\end{array}$ \\
\hline FM & $\begin{array}{l}\text { Failure mode }(\mathrm{S}=\text { shear; } \mathrm{SY}=\text { shear after } \\
\text { longitudinal rebar yielding; WS }=\text { web- } \\
\text { shear; } \mathrm{F}=\text { flexure })\end{array}$ \\
\hline$f_{\mathrm{R}, 1}$ & $\begin{array}{l}\text { Residual flexural tensile strength } \\
\text { corresponding to CMOD }=0.5 \mathrm{~mm}\end{array}$ \\
\hline$f_{\mathrm{R}, 3}$ & $\begin{array}{l}\text { Residual flexural tensile strength } \\
\text { corresponding to CMOD }=2.5 \mathrm{~mm}\end{array}$ \\
\hline$M_{\mathrm{Ed}}$ & Applied moment \\
\hline$N_{\text {Ed }}$ & Applied axial force \\
\hline$V_{\mathrm{c}}$ & Shear strength provided by concrete \\
\hline$V_{\mathrm{c}, \mathrm{F}}$ & $\begin{array}{l}\text { Shear strength provided by fibre reinforced } \\
\text { concrete }\end{array}$ \\
\hline$V_{\mathrm{Ed}}$ & Applied shear force \\
\hline$V_{\mathrm{f}}$ & Fibre volume fraction \\
\hline$V_{\mathrm{R}, \max }$ & Shear force at shear compression failure \\
\hline$V_{\mathrm{s}}$ & $\begin{array}{l}\text { Shear strength provided by web } \\
\text { reinforcement }\end{array}$ \\
\hline$V_{\mathrm{u}}$ & Shear strength \\
\hline$V_{\mathrm{u}, \mathrm{FRC}}$ & Shear strength of FRC elements \\
\hline$V_{\mathrm{u}, \mathrm{RS}}$ & Shear strength of reference samples \\
\hline $\begin{array}{l}V_{\mathrm{u}} / \\
V_{\mathrm{u}, \text { code }}\end{array}$ & Model safety factor \\
\hline$w_{\mathrm{u}}$ & $\begin{array}{l}\text { Maximum crack opening accepted in } \\
\text { structural design }\end{array}$ \\
\hline$z$ & Internal lever arm \\
\hline$\gamma_{\mathrm{c}}$ & $\begin{array}{l}\text { Strength reduction factor according to } \\
\text { Eurocode } 2 \text { and Model Code } 2010\end{array}$ \\
\hline$\varepsilon_{\mathrm{x}}$ & $\begin{array}{l}\text { Longitudinal strain calculated at mid-depth } \\
\text { of } d\end{array}$ \\
\hline$\theta$ & Angle of inclination of shear cracks \\
\hline$\rho$ & Longitudinal reinforcement ratio \\
\hline$\rho_{\mathrm{w}}$ & Web reinforcement ratio \\
\hline$\sigma_{\mathrm{p}}$ & $\begin{array}{l}\text { Compressive stress due to effective } \\
\text { prestress }\end{array}$ \\
\hline
\end{tabular}

\section{Introduction}

The use of fibres as shear reinforcement in Reinforced Concrete (RC) beams was mainly studied during the past three decades, even if the majority of these studied was carried out in the 2000s (Fig. 1). Fibres substantially enhance the shear strength and deformation capacity of structural elements $[1,2]$ in either vibrated [3-9] or self-compacting concrete [10, 11]; fibres also proved to be very effective in extruded concrete members [12]. Therefore, the effectiveness of fibres in enhancing the shear resistance is widely recognized in the scientific community. So far, the largest number of these studies dealt with steel fibres [3-6, 8-12] even if there was a recent growing interest on macro-synthetic ones [7].

Recent design guidelines allow to use fibres as shear reinforcement [13-15]. RILEM TC 162-TDF [13] proposed pioneer guidelines where fibre contribution to shear resistance was added to the concrete one as a separate term (based on post-cracking residual strengths). In other research studies, fibres and concrete contributions are generally not considered as additional terms since fibres markedly influence the typical mechanisms of shear transfer present in RC element (especially aggregate interlock); Fiber Rein-forced Concrete (FRC) can be considered as a unique composite material characterized by significant tough-ness properties after cracking (due to the bridging effect of fibres). This concept was adopted in the recent Model Code 2010 (hereafter MC2010) [14], where the positive effect of fibres in shear is consid-ered as an enhancement of concrete contribution. The latter was modelled in MC2010 by two different analytical equations (welldiscussed in the following sections) based on the postcracking residual strength provided by FRC, evaluated according to EN 14651 [16]. Consequently, a material mechanical character-ization of FRC is required by MC2010.

Figure 1 shows the number of publications (indexed papers) with experimental results from shear tests on FRC elements in the last 30 years (between 1985 and 2016). It can be observed that the majority of experimental tests $(72 \%)$ was carried out without providing any FRC mechanical characterization (only fibre type and amount are given), making difficult the use of these results by researchers. Only $28 \%$ of papers provides post-cracking mechanical properties of FRC, even if different characterization methods were 


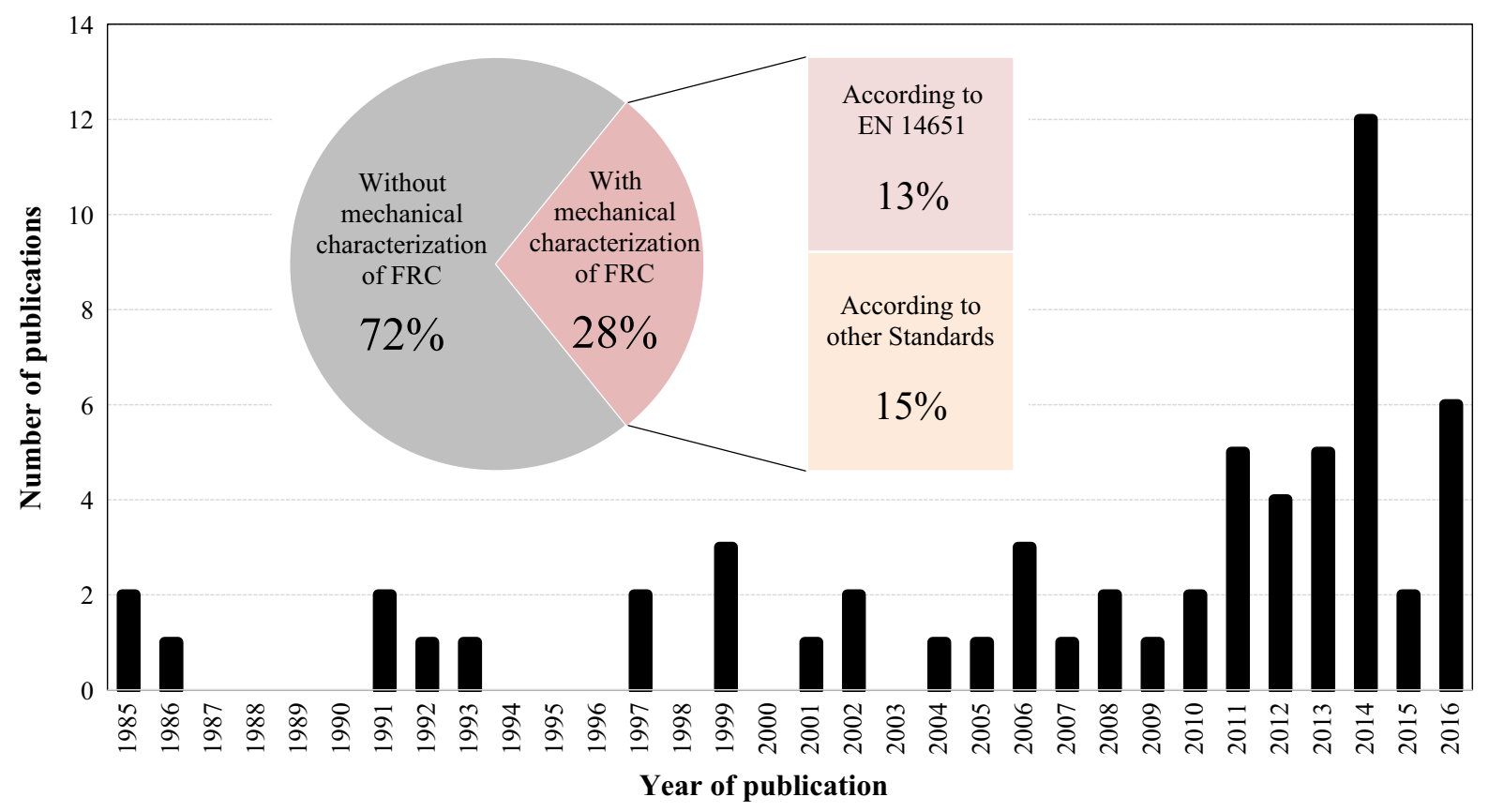

Fig. 1 Papers about shear behaviour on FRC beams

applied. Less than half of them provides a mechanical characterization according to EN 14651 and, so far, only very few recent papers tried to link other tests to EN 14651 [17, 18]. Consequently, shear strength of elements reinforced by fibres is predicted by using formulations generally developed from a limited set of tests results [19, 20] or from literature-derived database [21-24], where most of them do not provide any FRC characterization [21, 22]. In fact, it is very difficult to merge experimental results from different researches when reported data are different $[25,26]$ or important parameters are not given.

In this context, this paper neither proposes a new formula to add to the already long list nor collects data from other Authors. The objective is to provide a comprehensive shear database to the scientific community, which allows both to improve exiting analytical models and to develop new design formulations in shear. The strength of this database is to have qualified and detailed compilation of data about FRC beams subjected to shear, merging the experiences carried out in the past decades at the University of Brescia and at the Universitat Politècnica de València. The geometry, reinforcement details, post-cracking residual strengths according to EN $14651\left(f_{\mathrm{R}, 1}\right.$ and $\left.f_{\mathrm{R}, 3}\right)$ and the experimental results of 93 beams in FRC and their related 78 sample in RC (with or without web reinforcement) are presented. In addition, the database was analysed in order to capture the effect of the typical factors affecting the shear strength in case of FRC beams, as well as to study the increase in shear strength due to fibres addition. The shear formulations of both Eurocode 2 (hereafter EC2) [27] and MC2010 [14] for RC and FRC elements were compared against the database in order to highlight differences and inadequacy on shear strength predictions.

\section{Database of FRC elements under shear loading}

A comprehensive experimental database involving shear tests on beams reinforced by fibres (either steel and macro-synthetic one) is shown in Table 1. In addition, Table 2 lists the reference samples (RS) in RC made with or without web reinforcement of the beams reported in Table 1, allowing to evaluate the fibres influence on shear strength. This database was compiled from 12 experimental studies performed between 2006 and 2017 at the University of Brescia [28-36] and at the Universitat Politècnica de València [37-39]. The database contains test results of 171 


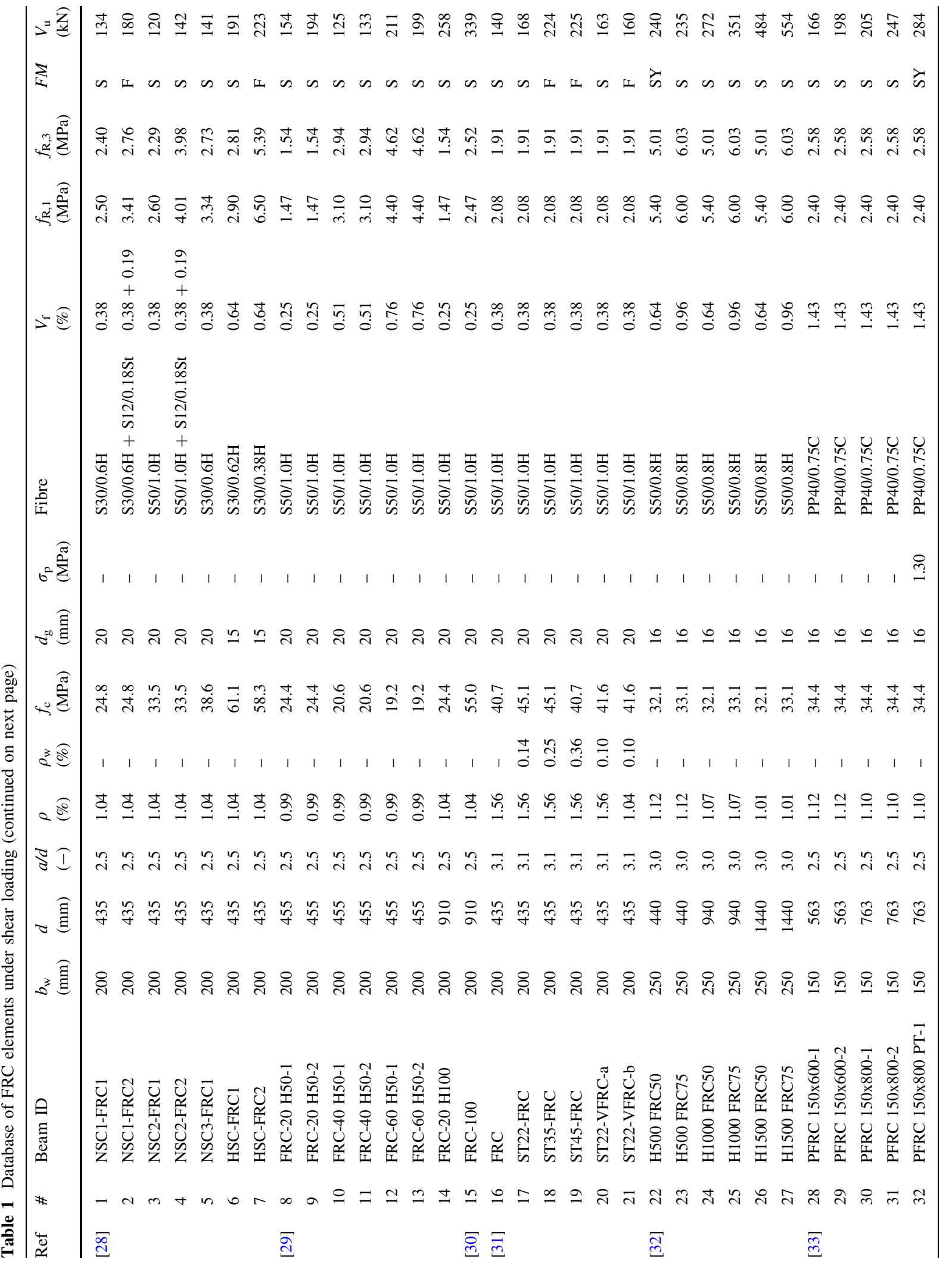




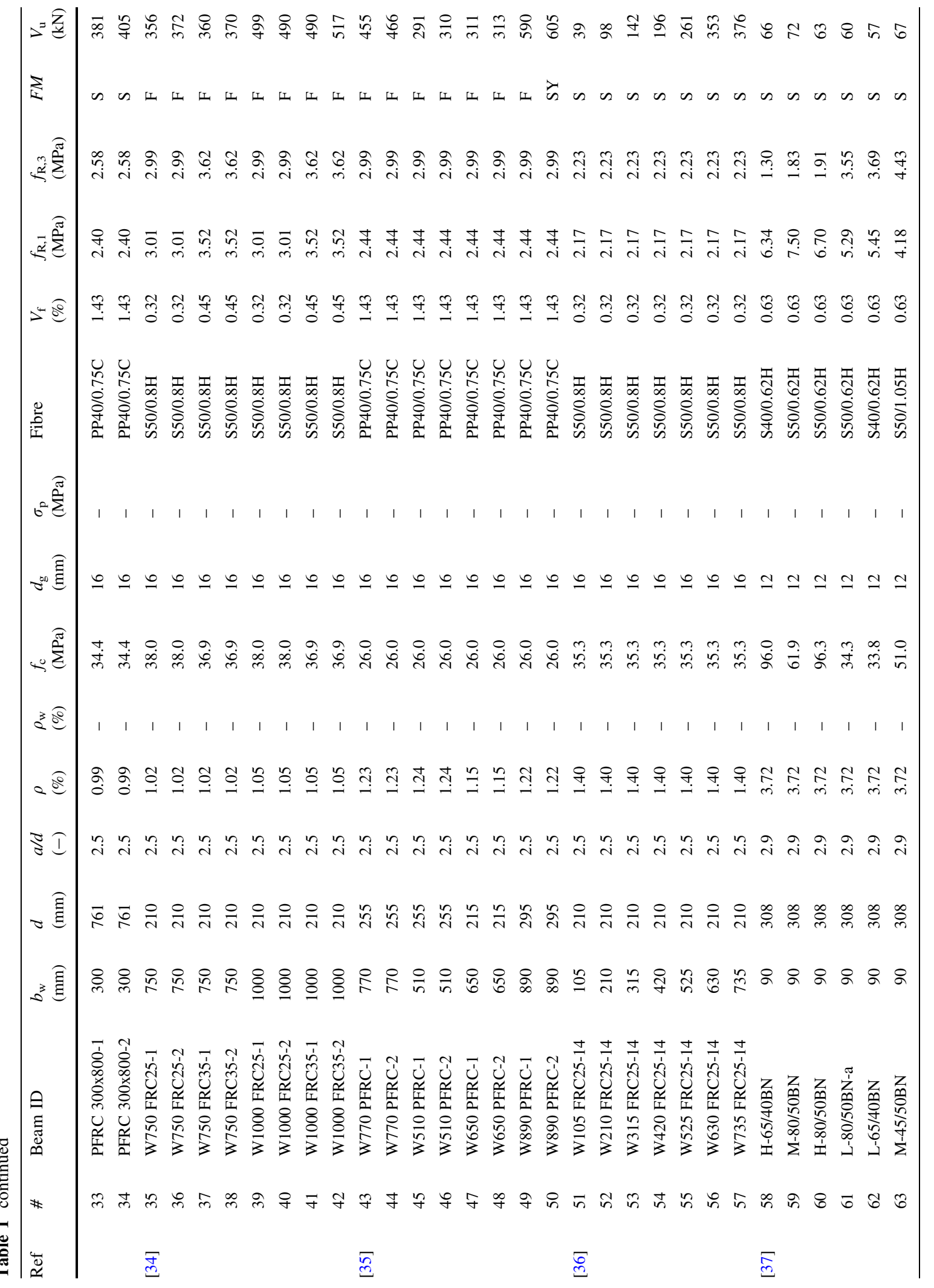




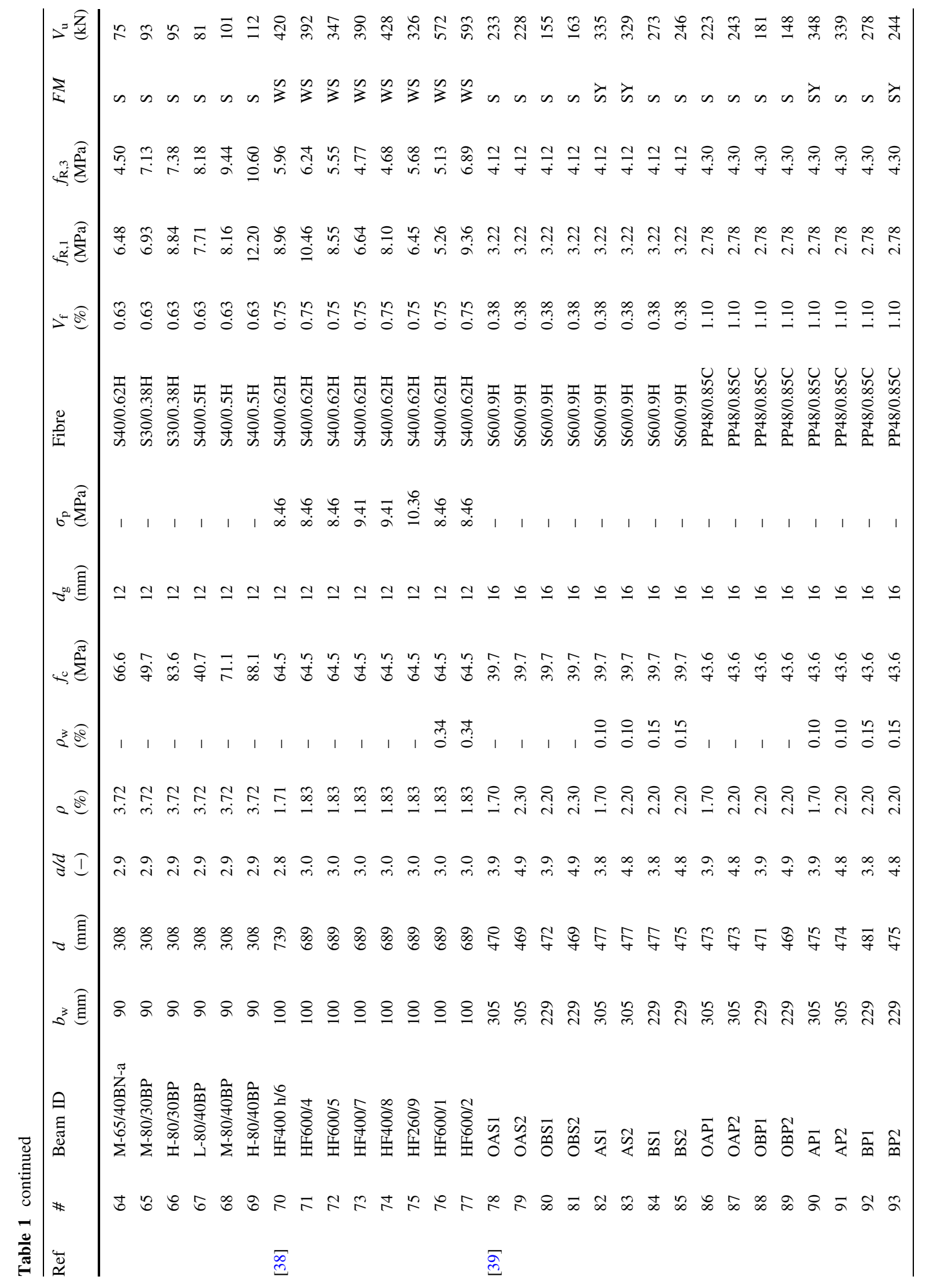


Table 2 Database of reference samples in RC (continued on next page)

\begin{tabular}{|c|c|c|c|c|c|c|c|c|c|c|c|c|}
\hline Ref & $\#$ & Beam ID & $b_{\mathrm{w}}(\mathrm{mm})$ & $d(\mathrm{~mm})$ & $a / d(-)$ & $\rho(\%)$ & $\rho_{\mathrm{w}}(\%)$ & $f_{\mathrm{c}}(\mathrm{MPa})$ & $d_{\mathrm{g}}(\mathrm{mm})$ & $\sigma_{\mathrm{p}}(\mathrm{MPa})$ & FM & $V_{\mathrm{u}}(\mathrm{kN})$ \\
\hline \multirow[t]{4}{*}{ [28] } & 94 & NSC1-PC & 200 & 435 & 2.5 & 1.04 & - & 24.8 & 20 & - & $\mathrm{S}$ & 69 \\
\hline & 95 & NSC2-PC & 200 & 435 & 2.5 & 1.04 & - & 33.5 & 20 & - & $\mathrm{S}$ & 84 \\
\hline & 96 & NSC3-PC & 200 & 435 & 2.5 & 1.04 & - & 38.6 & 20 & - & $\mathrm{S}$ & 83 \\
\hline & 97 & HSC-PC & 200 & 435 & 2.5 & 1.04 & - & 60.5 & 15 & - & $\mathrm{S}$ & 113 \\
\hline \multirow[t]{6}{*}{ [29] } & 98 & PC H50-1 & 200 & 455 & 2.5 & 0.99 & - & 25.9 & 20 & - & $\mathrm{S}$ & 105 \\
\hline & 99 & PC H50-2 & 200 & 455 & 2.5 & 0.99 & - & 25.9 & 20 & - & $\mathrm{S}$ & 110 \\
\hline & 100 & MSR H50-1 & 200 & 455 & 2.5 & 0.99 & 0.17 & 25.9 & 20 & - & $\mathrm{S}$ & 170 \\
\hline & 101 & MSR H50-2 & 200 & 455 & 2.5 & 0.99 & 0.17 & 25.9 & 20 & - & $\mathrm{S}$ & 153 \\
\hline & 102 & PC H100 & 200 & 910 & 2.5 & 1.04 & - & 25.9 & 20 & - & $\mathrm{S}$ & 194 \\
\hline & 103 & MSR H100 & 200 & 910 & 2.5 & 1.04 & 0.08 & 25.9 & 20 & - & $\mathrm{S}$ & 329 \\
\hline [30] & 104 & PC-100 & 200 & 910 & 2.5 & 1.04 & - & 55.0 & 20 & - & $\mathrm{S}$ & 208 \\
\hline \multirow[t]{4}{*}{ [31] } & 105 & $\mathrm{PC}$ & 200 & 435 & 3.1 & 1.56 & - & 44.0 & 20 & - & $\mathrm{S}$ & 103 \\
\hline & 106 & ST22 & 200 & 435 & 3.1 & 1.56 & 0.14 & 40.3 & 20 & - & $\mathrm{S}$ & 171 \\
\hline & 107 & ST35 & 200 & 435 & 3.1 & 1.56 & 0.25 & 40.3 & 20 & - & $\mathrm{S}$ & 209 \\
\hline & 108 & ST45 & 200 & 435 & 3.1 & 1.56 & 0.36 & 44.0 & 20 & - & $\mathrm{F}$ & 220 \\
\hline \multirow[t]{3}{*}{ [32] } & 109 & H500 PC & 250 & 440 & 3.0 & 1.12 & - & 38.7 & 16 & - & $\mathrm{S}$ & 116 \\
\hline & 110 & H1000 PC & 250 & 940 & 3.0 & 1.07 & - & 38.7 & 16 & - & $\mathrm{S}$ & 188 \\
\hline & 111 & H1500 PC & 250 & 1440 & 3.0 & 1.01 & - & 38.7 & 16 & - & $\mathrm{S}$ & 211 \\
\hline \multirow[t]{12}{*}{ [33] } & 112 & PC $150 \times 600-1$ & 150 & 563 & 2.5 & 1.12 & - & 30.4 & 16 & - & $\mathrm{S}$ & 89 \\
\hline & 113 & PC $150 \times 600-2$ & 150 & 563 & 2.5 & 1.12 & - & 30.4 & 16 & - & $\mathrm{S}$ & 64 \\
\hline & 114 & MSR 150x600-1 & 150 & 563 & 2.5 & 1.12 & 0.32 & 30.4 & 16 & - & $\mathrm{F}$ & 185 \\
\hline & 115 & MSR 150x600-2 & 150 & 563 & 2.5 & 1.12 & 0.32 & 30.4 & 16 & - & $\mathrm{F}$ & 204 \\
\hline & 116 & PC $150 \times 800-1$ & 150 & 763 & 2.5 & 1.10 & - & 30.4 & 16 & - & $\mathrm{S}$ & 91 \\
\hline & 117 & PC $150 \times 800-2$ & 150 & 763 & 2.5 & 1.10 & - & 30.4 & 16 & - & $\mathrm{S}$ & 101 \\
\hline & 118 & MSR 150x800-1 & 150 & 763 & 2.5 & 1.10 & 0.32 & 30.4 & 16 & - & $\mathrm{F}$ & 244 \\
\hline & 119 & MSR 150x800-2 & 150 & 763 & 2.5 & 1.10 & 0.32 & 30.4 & 16 & - & $\mathrm{F}$ & 250 \\
\hline & 120 & PC 150x800 PT-1 & 150 & 763 & 2.5 & 1.10 & - & 30.4 & 16 & 1.30 & $\mathrm{~S}$ & 199 \\
\hline & 121 & PC 300x800-1 & 300 & 761 & 2.5 & 0.99 & - & 30.4 & 16 & - & $\mathrm{S}$ & 183 \\
\hline & 122 & MSR 300x800-1 & 300 & 761 & 2.5 & 0.99 & 0.16 & 30.4 & 16 & - & $\mathrm{F}$ & 424 \\
\hline & 123 & MSR 300x800-2 & 300 & 761 & 2.5 & 0.99 & 0.16 & 30.4 & 16 & - & $\mathrm{F}$ & 436 \\
\hline \multirow[t]{7}{*}{ [34] } & 124 & W750 PC-1 & 750 & 210 & 2.5 & 1.02 & - & 40.5 & 16 & - & $\mathrm{S}$ & 238 \\
\hline & 125 & W750 MSR-1 & 750 & 210 & 2.5 & 1.02 & 0.10 & 40.5 & 16 & - & $\mathrm{F}$ & 335 \\
\hline & 126 & W750 MSR-2 & 750 & 210 & 2.5 & 1.02 & 0.10 & 40.5 & 16 & - & $\mathrm{F}$ & 338 \\
\hline & 127 & W1000 PC-1 & 1000 & 210 & 2.5 & 1.05 & - & 40.5 & 16 & - & $\mathrm{S}$ & 338 \\
\hline & 128 & W1000 PC-2 & 1000 & 210 & 2.5 & 1.05 & - & 40.5 & 16 & - & $\mathrm{S}$ & 311 \\
\hline & 129 & W1000 MSR-1 & 1000 & 210 & 2.5 & 1.05 & 0.11 & 40.5 & 16 & - & $\mathrm{F}$ & 465 \\
\hline & 130 & W1000 MSR-2 & 1000 & 210 & 2.5 & 1.05 & 0.11 & 40.5 & 16 & - & $\mathrm{F}$ & 442 \\
\hline \multirow[t]{6}{*}{ [35] } & 131 & W430 PC-1 & 430 & 215 & 2.5 & 1.30 & - & 31.2 & 16 & - & $\mathrm{S}$ & 170 \\
\hline & 132 & W430 PC-2 & 430 & 215 & 2.5 & 1.30 & - & 31.2 & 16 & - & $\mathrm{S}$ & 177 \\
\hline & 133 & W770 PC-1 & 770 & 255 & 2.5 & 1.23 & - & 31.2 & 16 & - & $\mathrm{S}$ & 338 \\
\hline & 134 & W770 PC-2 & 770 & 255 & 2.5 & 1.23 & - & 31.2 & 16 & - & $\mathrm{S}$ & 337 \\
\hline & 135 & W770 MSR-1 & 770 & 255 & 2.5 & 1.23 & 0.10 & 31.2 & 16 & - & $\mathrm{F}$ & 468 \\
\hline & 136 & W770 MSR-2 & 770 & 255 & 2.5 & 1.23 & 0.10 & 31.2 & 16 & - & $\mathrm{F}$ & 462 \\
\hline
\end{tabular}


Table 2 continued

\begin{tabular}{|c|c|c|c|c|c|c|c|c|c|c|c|c|}
\hline Ref & $\#$ & Beam ID & $b_{\mathrm{w}}(\mathrm{mm})$ & $d(\mathrm{~mm})$ & $a / d(-)$ & $\rho(\%)$ & $\rho_{\mathrm{w}}(\%)$ & $f_{\mathrm{c}}(\mathrm{MPa})$ & $d_{\mathrm{g}}(\mathrm{mm})$ & $\sigma_{\mathrm{p}}(\mathrm{MPa})$ & FM & $V_{\mathrm{u}}(\mathrm{kN})$ \\
\hline \multirow[t]{17}{*}{ [36] } & 137 & W105 PC-14 & 105 & 210 & 2.5 & 1.40 & - & 40.4 & 16 & - & $\mathrm{S}$ & 26 \\
\hline & 138 & W210 PC-14 & 210 & 210 & 2.5 & 1.40 & - & 40.4 & 16 & - & $\mathrm{S}$ & 64 \\
\hline & 139 & W315 PC-14 & 315 & 210 & 2.5 & 1.40 & - & 40.4 & 16 & - & $\mathrm{S}$ & 97 \\
\hline & 140 & W420 PC-14 & 420 & 210 & 2.5 & 1.40 & - & 40.4 & 16 & - & $\mathrm{S}$ & 157 \\
\hline & 141 & W525 PC-14 & 525 & 210 & 2.5 & 1.40 & - & 40.4 & 16 & - & $\mathrm{S}$ & 173 \\
\hline & 142 & W630 PC-14 & 630 & 210 & 2.5 & 1.40 & - & 40.4 & 16 & - & $\mathrm{S}$ & 204 \\
\hline & 143 & W735 PC-14 & 735 & 210 & 2.5 & 1.40 & - & 40.4 & 16 & - & $\mathrm{S}$ & 242 \\
\hline & 144 & W105 PC-20 & 105 & 210 & 2.5 & 1.42 & - & 39.3 & 16 & - & $\mathrm{S}$ & 28 \\
\hline & 145 & W210 PC-20 & 210 & 210 & 2.5 & 1.42 & - & 39.3 & 16 & - & $\mathrm{S}$ & 53 \\
\hline & 146 & W315 PC-20 & 315 & 210 & 2.5 & 1.42 & - & 39.3 & 16 & - & $\mathrm{S}$ & 89 \\
\hline & 147 & W420 PC-20 & 420 & 210 & 2.5 & 1.42 & - & 39.3 & 16 & - & $\mathrm{S}$ & 121 \\
\hline & 148 & W525 PC-20 & 525 & 210 & 2.5 & 1.42 & - & 39.3 & 16 & - & $\mathrm{S}$ & 153 \\
\hline & 149 & W630 PC-20 & 630 & 210 & 2.5 & 1.42 & - & 39.3 & 16 & - & $\mathrm{S}$ & 204 \\
\hline & 150 & W735 PC-20 & 735 & 210 & 2.5 & 1.42 & - & 39.3 & 16 & - & $\mathrm{S}$ & 243 \\
\hline & 151 & W315 PC-24 & 315 & 210 & 2.5 & 1.37 & - & 39.3 & 16 & - & $\mathrm{S}$ & 102 \\
\hline & 152 & W630 PC-24 & 630 & 210 & 2.5 & 1.37 & - & 39.3 & 16 & - & $\mathrm{S}$ & 190 \\
\hline & 153 & W735 PC-24 & 735 & 210 & 2.5 & 1.46 & - & 39.3 & 16 & - & $\mathrm{S}$ & 240 \\
\hline \multirow[t]{9}{*}{ [37] } & 154 & M-0 & 90 & 308 & 2.9 & 3.72 & - & 50.5 & 12 & - & $\mathrm{S}$ & 38 \\
\hline & 155 & $\mathrm{H}-0$ & 90 & 308 & 2.9 & 3.72 & - & 85.6 & 12 & - & $\mathrm{S}$ & 40 \\
\hline & 156 & М-Ф6 & 90 & 308 & 2.9 & 3.72 & 0.16 & 48.3 & 12 & - & $\mathrm{S}$ & 74 \\
\hline & 157 & Н-Ф6 & 90 & 298 & 3.0 & 3.84 & 0.16 & 74.5 & 12 & - & $\mathrm{S}$ & 79 \\
\hline & 158 & L-Ф6 & 90 & 298 & 3.0 & 3.84 & 0.16 & 41.9 & 12 & - & $\mathrm{S}$ & 86 \\
\hline & 159 & A & 200 & 650 & 3.2 & 3.02 & 0.17 & 50.5 & 16 & - & $\mathrm{S}$ & 358 \\
\hline & 160 & B & 200 & 650 & 3.2 & 3.02 & 0.17 & 53.8 & 16 & - & $\mathrm{S}$ & 365 \\
\hline & 161 & М-Ф8 & 90 & 308 & 2.9 & 3.72 & 0.37 & 50.5 & 12 & - & $\mathrm{S}$ & 81 \\
\hline & 162 & Н-Ф8 & 90 & 308 & 2.9 & 3.72 & 0.37 & 85.6 & 12 & - & $\mathrm{S}$ & 94 \\
\hline [38] & 163 & H600/3 & 100 & 689 & 3.0 & 1.83 & 0.34 & 64.5 & 12 & 8.46 & WS & 491 \\
\hline \multirow[t]{8}{*}{ [39] } & 164 & OA1 & 305 & 473 & 3.9 & 1.70 & - & 40.6 & 16 & - & $\mathrm{S}$ & 156 \\
\hline & 165 & OA2 & 305 & 474 & 4.8 & 2.20 & - & 40.6 & 16 & - & $\mathrm{S}$ & 169 \\
\hline & 166 & OB1 & 229 & 473 & 3.9 & 2.20 & - & 40.6 & 16 & - & $\mathrm{S}$ & 137 \\
\hline & 167 & OB2 & 229 & 471 & 4.8 & 2.20 & - & 40.6 & 16 & - & $\mathrm{S}$ & 113 \\
\hline & 168 & A1 & 305 & 473 & 3.9 & 1.70 & 0.10 & 40.6 & 16 & - & $\mathrm{S}$ & 236 \\
\hline & 169 & $\mathrm{~A} 2$ & 305 & 473 & 4.8 & 2.20 & 0.10 & 40.6 & 16 & - & $\mathrm{S}$ & 239 \\
\hline & 170 & B1 & 229 & 474 & 3.9 & 2.20 & 0.15 & 40.6 & 16 & - & $\mathrm{S}$ & 234 \\
\hline & 171 & B2 & 229 & 474 & 4.8 & 2.20 & 0.15 & 40.6 & 16 & - & S & 220 \\
\hline
\end{tabular}

beams (117 and 54 tested at the University of Brescia and Universitat Politècnica de València, respectively), where 93 are made with FRC (Table 1) and 78 are in $\mathrm{RC}$ made with or without web reinforcement (Table 2). The majority of the beams exhibited either a shear or web-shear failure mode. In case of FRC samples, 73 beams failed in shear and 20 in flexure, while for RC beams 65 exhibited a shear failure and 13 a flexure one. All members failing in flexure are anyway reported in this database since they might give data for further specific analysis and applications. However, these samples were not considered in the database analyses presented in Sect. 3. It should be also noticed that 9 FRC beams (over 93) and 2 RC beams (over 78) of database are prestressed. 
For the collection of a consistent and comprehensive database, the following parameters are showed for each beam:

- order number (\#);

- beam ID;

- web width $\left(b_{\mathrm{w}}\right)$;

- effective depth $(d)$;

- shear span to effective depth ratio $(a / d)$;

- longitudinal reinforcement ratio $(\rho)$;

- web reinforcement ratio $\left(\rho_{\mathrm{w}}\right)$;

- cylinder concrete compressive strength $\left(f_{\mathrm{c}}\right)$;

- maximum aggregate size $\left(d_{\mathrm{g}}\right)$;

- compressive stress due to effective prestress $\left(\sigma_{\mathrm{p}}\right)$;

- fibre type in terms of: material $(\mathrm{S}=$ steel, $\mathrm{PP}=$ polypropylene), length in $\mathrm{mm}$ /diameter in $\mathrm{mm}$, shape $(\mathrm{H}=$ hooked ends, $\mathrm{St}=$ straight, $\mathrm{C}=$ crimped). As an example, the designation $\mathrm{S} 30 / 0.6 \mathrm{H}$ refers to a steel fibres $30 \mathrm{~mm}$ long, with diameter of $0.6 \mathrm{~mm}$ and hooked ends.

- fibres volume fraction $\left(V_{\mathrm{f}}\right)$;

- residual flexural tensile strengths $f_{\mathrm{R}, 1}$ and $f_{\mathrm{R}, 3}$ (in accordance to EN 14651 [16]) corresponding to $\mathrm{CMOD}=0.5 \mathrm{~mm}$ and $\mathrm{CMOD}=2.5 \mathrm{~mm}$, respectively;

- $\quad$ failure mode (FM): $\mathrm{S}=$ shear; $\mathrm{SY}=$ shear after longitudinal rebar yielding; WS = web-shear, namely the failure due to diagonal tension developed before flexural cracking; $\mathrm{F}=$ flexure;

- experimental shear strength $\left(V_{u}\right)$.

The cross section of beams in this shear database is rectangular, except for samples in Refs. [37] and [38] that are characterized by I-shape. More details about flange dimensions can be found in [37] and [38], as well as in Ref. [11] a deep analysis on samples from 58 to 69 is given. Moreover, it is worth mentioning that both longitudinal and web reinforcement adopted in the database are made with the steel most commonly used in Europe, i.e. B500C [27].

\section{Evaluation of the shear database}

Figure 2 shows the distribution of the main parameters affecting the shear strength in the database considering the 73 specimens failed in shear. It can be observed that wide ranges of selected parameters are considered. $d$ varies from 210 to $1440 \mathrm{~mm}$ with $70 \%$ of beams under $500 \mathrm{~mm}$, while $a / d$ ratio ranges from 2.5

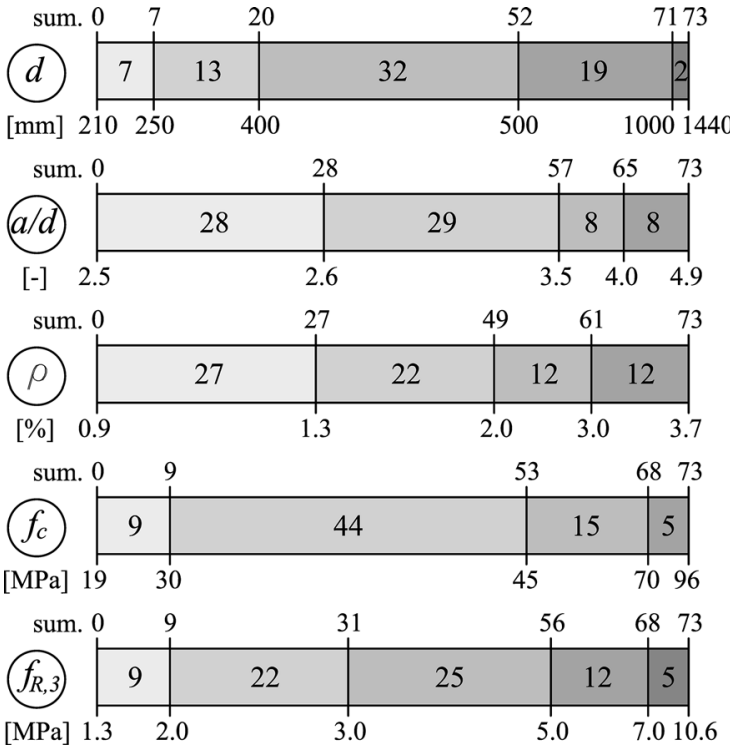

Fig. 2 Distribution of parameters in the shear database for FRC elements (only shear failure)

to 3.5 for the majority of samples (80\%). Typical $\rho$ adopted in practice (up to $1.3 \%$ ) can be observed for $40 \%$ of samples, while, in order to induce a shear failure, higher amount of longitudinal reinforcement was used elsewhere (up to $3.7 \%$ ). Different concrete compressive classes were also studied, with $f_{\mathrm{c}}$ ranging from 19 to $96 \mathrm{MPa}$ (with $70 \%$ of samples character-ized by a $f_{\mathrm{c}}$ smaller than $45 \mathrm{MPa}$ ). Finally, the database incorporate FRCs characterized by a signif-icantly wide range of residual mechanical properties (both softening and hardening materials under flex-ure): $f_{\mathrm{R}, 3}$ varying from 1.3 to $10.6 \mathrm{MPa}$. In particular, 31 samples have a $f_{\mathrm{R}, 3}$ smaller than 3.0, followed by 25 specimens in the range between 3 and $5 \mathrm{MPa}$ and the remaining 17 beams with higher residual mechanical properties.

In these parameter ranges, the increase in shear strength due to fibre addition was analysed by comparing each FRC beam (fibre only, Table 1) to its reference sample (without web reinforcement, Table 2). In particular, the ratio between the shear strength of FRC beams $\left(V_{\mathrm{u}, \mathrm{FRC}}\right)$ and the one of their reference samples $\left(V_{\mathrm{u}, \mathrm{RS}}\right)$ was calculated and plotted as a function of $f_{\mathrm{R}, 3}$ in Fig. 3. This allows to obtain the fibre contribution on shear strength, excluding the influence of all other affecting parameter (i.e. $d, a / d, \rho, f_{\mathrm{c}}$ ), which are equal between each FRC sample and its corresponding reference specimen. $f_{\mathrm{R}, 3}$ was chosen 


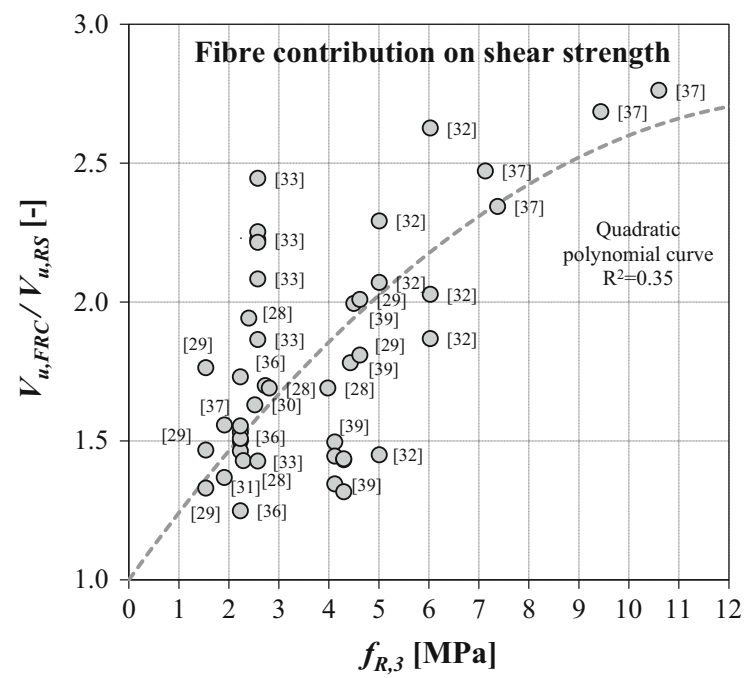

Fig. 3 Increase in shear strength due to effect of fibres

since it characterizes the post-cracking performance given by different fibres (which differ in length, shape, material and amount) at ultimate limit state. Figure 3 clearly shows that an increase of $f_{\mathrm{R}, 3}$ determines a significant increment of shear strength, resulting in a rather fundamental tool for engineers for both predesign and verification phases against shear loading. For instance, a $f_{\mathrm{R}, 3}$ of 2 and $5 \mathrm{MPa}$ lead to a shear strength increment of about 50 and $100 \%$, respectively. The parameter $f_{\mathrm{R}, 3}$ was related to shear strength increment by using the method of least squares (imposing an intercept $V_{\mathrm{u}, \mathrm{FRC}} / V_{\mathrm{u}, \mathrm{RS}}=1$ for

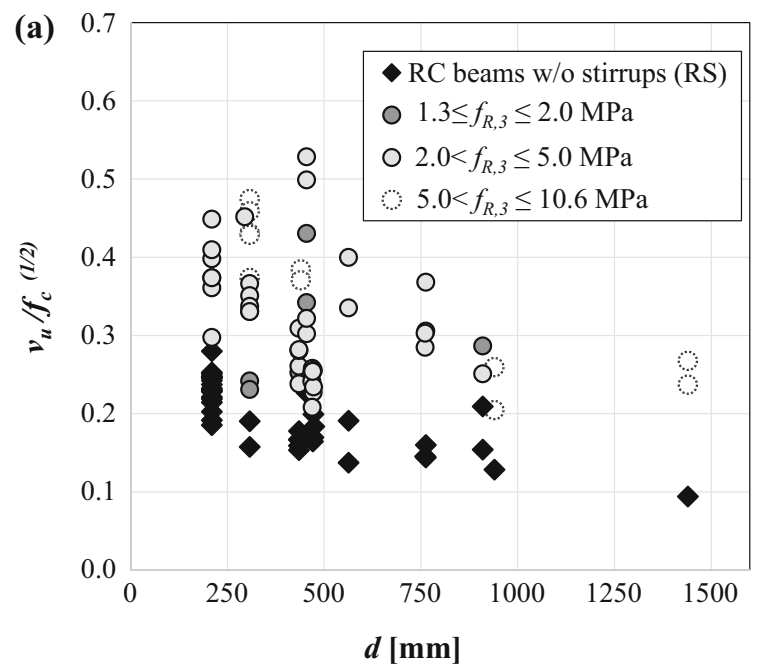

$f_{\mathrm{R}, 3}=0$ ) and it was observed that the best trend is a quadratic regression, even if it is characterized by a weak coefficient of determination $\left(R^{2}=0.35\right)$. The latter is due to the fact that for a given $f_{\mathrm{R}, 3}$ the ratio $V_{\mathrm{u}, \mathrm{FRC}} / V_{\mathrm{u}, \mathrm{RS}}$ showed a variability, as a consequence of the combined effect of both $f_{\mathrm{R}, 3}$ (coefficient of variations ranging between 10 and 40\% [40]) variability and shear strength dispersion (placing, compaction, beam geometry and fibre type can influence fibre distribution and orientation [41]). Moreover, the load at which the inclined shear cracking occurs is a function of the tensile strength of concrete, which in turn is a quite disperse material property. This also contributes, with the other factors as above-men-tioned, to the shear strength variability of elements reinforced by fibres only.

The influence of fibres on well-known parameters affecting the shear strength was evaluated as well. In particular, Fig. 4 shows the influence of fibres on the shear strength as a function of effective depth (Fig. 4a) and longitudinal reinforcement ratio (Fig. 4b). In this figure, the normalized shear strength $\left(v_{\mathrm{u}} / f_{\mathrm{c}}^{(1 / 2)}\right)$ is plotted as a function of the two parameters; moreover, FRC specimens were separated in three $f_{\mathrm{R}, 3}$ ranges. It can be observed that, as already stated by Minelli et al. [32] and Shoaib et al. [6], the database confirms that FRC beams are affected by size effect (Fig. 4a). This influence is similar to RC beams without web reinforcement up to an effective depth of $1000 \mathrm{~mm}$, after which the trend of the size effect law for FRC

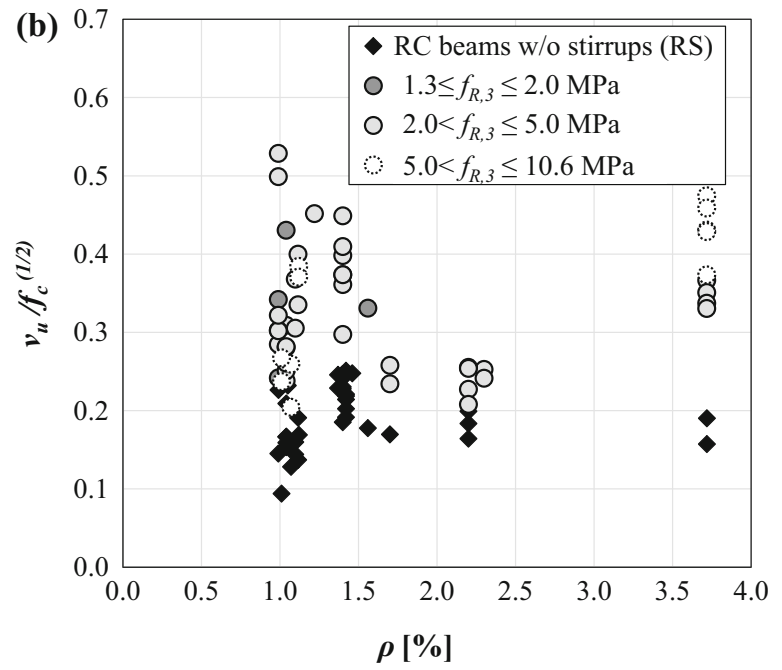

Fig. 4 Size effect trend for RC and FRC elements (a) and effect of fibres as the reinforcement ratio increases (b) 
differs and it seems that a lower bound is reached (horizontal asymptote). Comparing the three performance ranges shown in Fig. 4a, it can be also observed that the decrease in the shear at failure is similar up to $1000 \mathrm{~mm}$, underlining that the post-cracking performance of FRC does not significantly change the size effect law. Consequently, building codes could consider this positive effect of fibres in beams characterized by effective depth greater than $1000 \mathrm{~mm}$, while classical RC size effect law can be applied for FRC elements with $d \leq 1000 \mathrm{~mm}$. When considering the longitudinal reinforcement ratio, an increment of $\rho$ causes a similar increase of ultimate shear strength in both RC and FRC elements, even for higher values of $f_{\mathrm{R}, 3}$. This trend is also similar between the different FRC considered. Therefore, the longitudinal reinforcement influence on the shear strength seems not to clearly change from RC to FRC elements and its effects are comparable. The positive influence on the shear strength of the longitudinal reinforcement ratio is due to the increase in crack width for $\rho$ reduction that causes a decrease in the shear transferred across the inclined crack by dowel action and aggregate interlock. Similarly to $\rho$, either $f_{c}$ or $a / d$ influence resulted comparable both in RC and FRC samples. These database analysis underline that fibres mainly increase the shear strength of elements by transferring stresses across inclined shear cracks and by enhancing aggregate interlock mechanism [42-44].

\section{Comparison with design equations of EC2 and MC2010}

The shear strength predictions of two different analytical models recently included in MC2010 and developed for FRC beams were evaluated against the experimental results presented in the database. In addition, the provisions of their base models were also analysed against the reference samples listed in Table 2. In order to make this comparison more significant, the shear strength were calculated by assuming strength reduction factors $\left(\gamma_{c}\right.$ for EC2 and MC2010) equal to 1 and the mean values of the material mechanical properties. The mean value of tensile strength $f_{\mathrm{ct}}$ was evaluated according to Eq. 5.1-

$3 \mathrm{a}\left(f_{\mathrm{ct}}=0.3 \cdot\left(f_{\mathrm{ck}}\right)^{2 / 3}\right)$ and 5.1-3b $\left(f_{\mathrm{ct}}=2.12 \cdot \ln [1+\right.$ $\left.\left.0.1 \cdot\left(f_{c k}+8 \mathrm{MPa}\right)\right]\right)$ of MC2010 for concrete characterized by $f_{\mathrm{ck}} \leq 50 \mathrm{MPa}$ and $f_{\mathrm{ck}}>50 \mathrm{MPa}$, respectively. The characteristic value of the concrete compressive strength was calculated as $f_{\text {ck }}=f_{\mathrm{c}}-8 \mathrm{MPa}$ according to Eq. 5.1-1 of MC2010. In case of MC2010 shear models, when required, the control section was considered at a location $d$ from load point.

Table 3 summarize the shear formulations of these models for the prediction of the shear strength resistance (express in terms of SI units). Concerning FRC, the first model (Eq. (5) in Table 3) was built on the base formulation of EC2 (Eq. (1) in Table 3) [45] and it considers the fibre contribution by modifying the longitudinal reinforcement ratio. To the contrary, the second one (Eq. (7) in Table 3) was derived from the base formulation of MC2010 (Eq. (3) in Table 3) [46], which in turn is linked to the Modified Compression Field Theory [47]. Both formulations consider the fibre contribution not as a separate addendum but as an enhancement of the concrete contribution, as well as they adopt an ultimate residual tensile strength $\left(f_{\mathrm{Ftu}}\right)$. In case of Eq. (5), MC2010 suggests to estimate $f_{\mathrm{Ftu}}$ by a simplified linear model based on $f_{\mathrm{R}, 1}$ and $f_{\mathrm{R}, 3}$ (EN 14651), while in case of Eq. (7) it is suggested to evaluate it by direct tensile tests (without specifying the type of tensile tests). Since no direct tensile tests were carried out for any of the database series, the simplified linear model based on $f_{\mathrm{R}, 1}$ and $f_{\mathrm{R}, 3}$ (EN 14651) has been also applied in case of Eq. (7). Recent publications discussed also the possible influence of using the simplified linear model $\left(f_{\mathrm{R}, 1}\right.$ and $\left.f_{\mathrm{R}, 3}\right)$ on Eq. (7) [17, 48]. Amin et al. [17] studying steel FRC showed that that MC2010 simplified linear model might overestimate $f_{\mathrm{Ftu}}$, with direct consequence on the accuracy of the shear model [48]. Consequently, it should be noticed that the evaluation of Eq. (7) against database results could be also affected by the use of the simplified linear model for estimating $f_{\mathrm{Ftu}}$.

Figure 5 shows the comparison between the experimental and the ultimate shear strength predicted by the base models of EC2 (Eq. (1)) and MC2010 II level (Eq. (3)) for RC elements without web reinforcement. In this figure, specimens were ordered by increasing effective depth. It can be observed that both base models lead to good and very similar strength predictions. The mean value of the model safety factor $V_{\mathrm{u}} / V_{\mathrm{u} \text {,code }}$ resulted in both case greater than the unity, i.e. 1.08 and 1.10 for EC2 and MC2010 model with coefficient of variation equal to 0.19 . This 


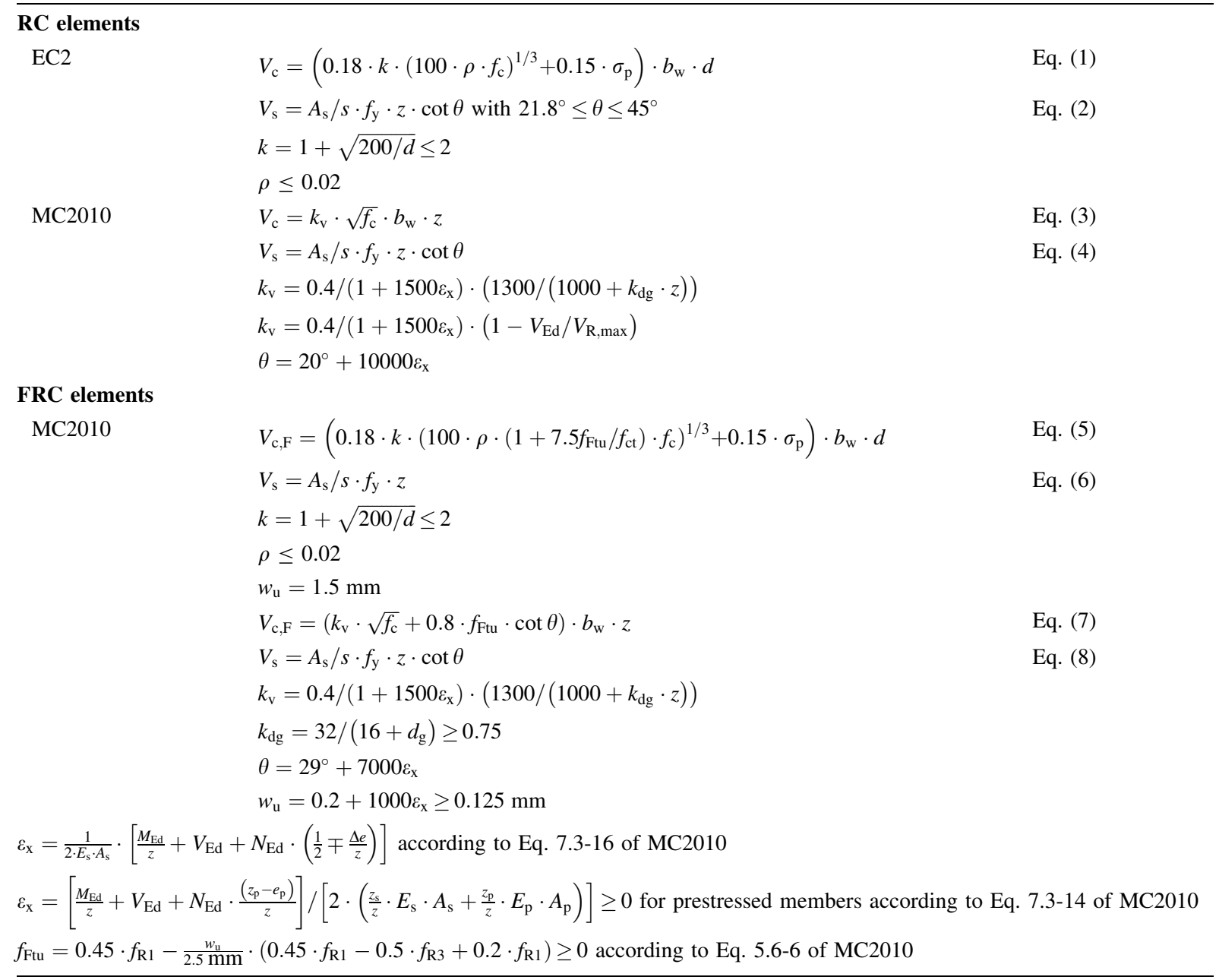

confirms that both models are comparable, as well as they are mainly characterized by conservative or slightly unconservative predictions. In addition, it is worth mentioning that both models show a decrement of the ratio $V_{\mathrm{u}} / V_{\mathrm{u}, \text { code }}$ when the effective depth increase: for $d$ up to $250 \mathrm{~mm}$ this ratio is generally greater than 1 , for $250<d \leq 1000 \mathrm{~mm}$ is around 1 , while it is smaller than 1 (unconservative) for $d>1000 \mathrm{~mm}$. Even if for $d$ greater than $1000 \mathrm{~mm}$ only one samples is present in the database (H1500 PC), this general downward trend of $V_{\mathrm{u}} / V_{\mathrm{u} \text {,code }}$ is clearly evident; this result underlines that $\mathrm{EC} 2$ and MC2010 could better take into account size effect in shear resistance of RC beams. To the contrary, no clear trend of $V_{\mathrm{u}} / V_{\mathrm{u}, \text { code }}$ was observed varying $\rho, a / d$ or $f_{\mathrm{c}}$. It is worth mentioning that both EC2 and MC2010 models resulted even more conservative in case of wide-shallow beams (W750 PC-1, W1000 PC-1 and 2, W430 PC-1 and 2, W770 PC-1 and 2) due also to the positive effect of width-to-effective depth ratio. More details about width-to-effective depth ratio influence on the shear strength can be found in [36].

Likewise Figs. 5 and 6 shows the predictions of both EC2 [Eq. (1) + Eq. (2)] and MC2010 III level [Eq. (3) + Eq. (4)] model for beams with web reinforcement. In case of EC2 model, the shear strength was assumed as the sum of $V_{\mathrm{c}}$ and $V_{\mathrm{s}}$ with $\theta=45^{\circ}$. It can be observed that, once again, both models are very 


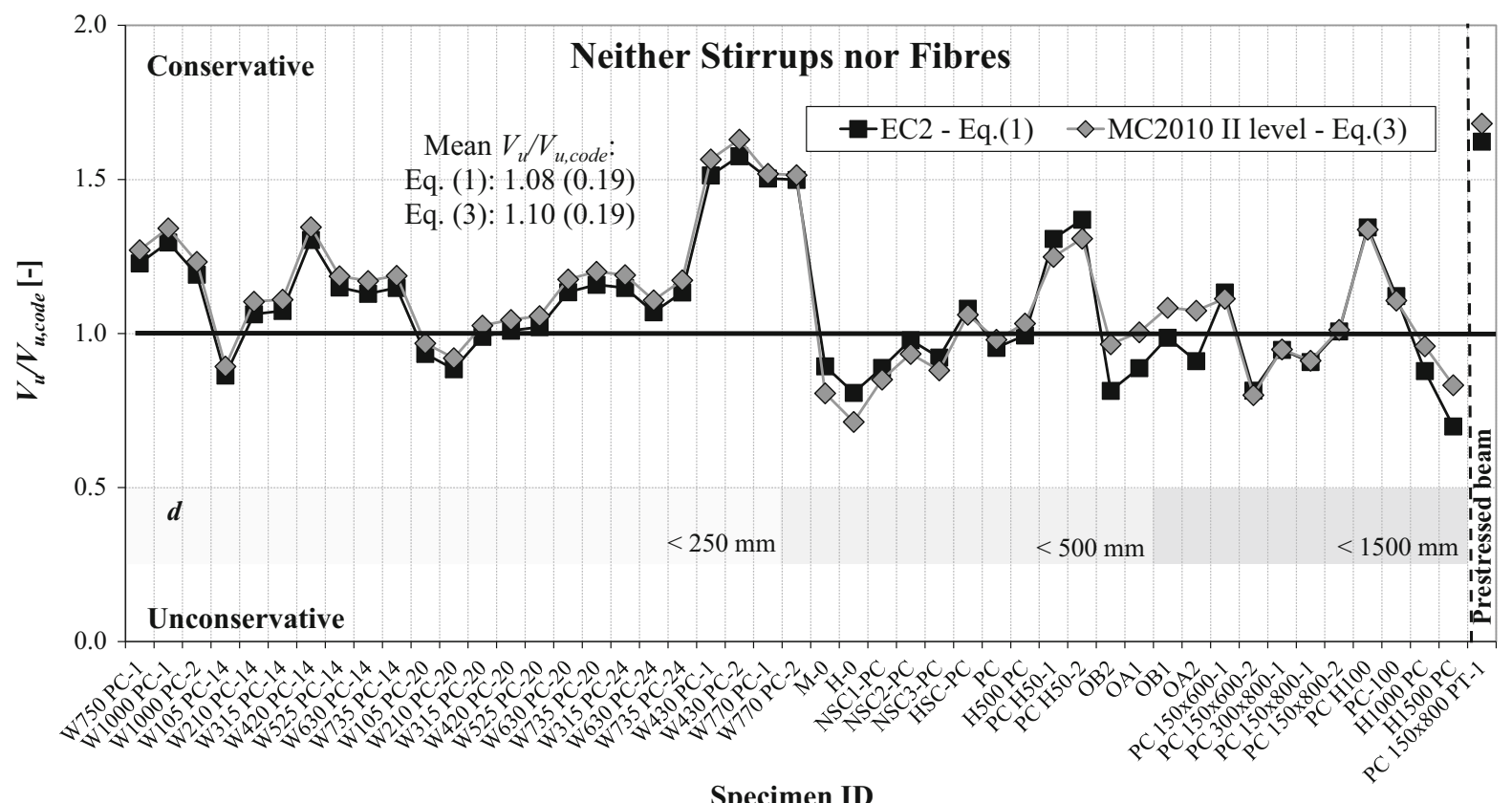

Fig. 5 Comparison against EC2 and Model Code 2010 shear model for beams without web reinforcement

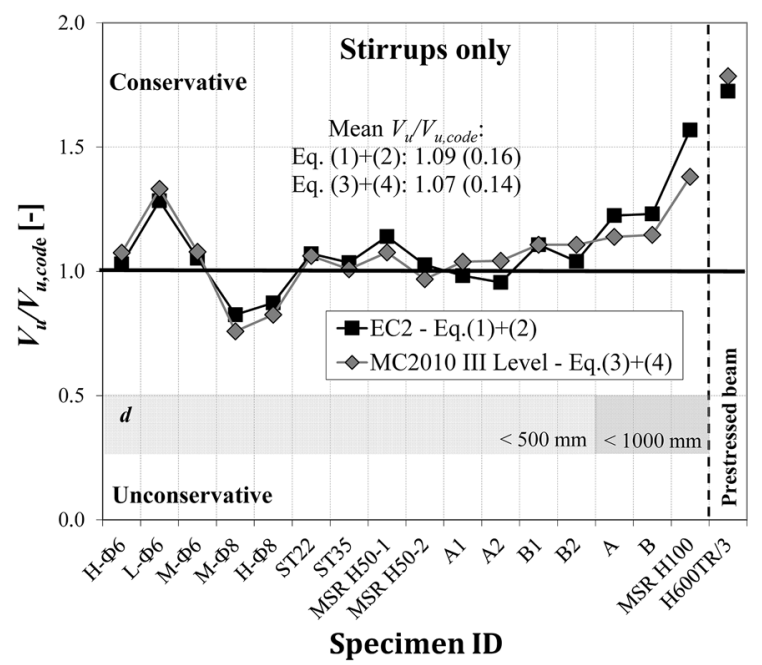

Fig. 6 Comparison against EC2 and Model Code 2010 shear model for beams with web reinforcement

similar and lead to good provisions, as well as they are generally conservative and characterized by a mean value of $V_{\mathrm{u}} / V_{\mathrm{u} \text {,code }}$ close to 1.10 . The prediction variability is $25 \%$ smaller as compared to beams without web reinforcement, as evidenced by the coefficient of variations. In addition, no variation of the ratio $V_{\mathrm{u}} / V_{\mathrm{u} \text {,code }}$ is remarkable by varying $d, \rho, a / d$ or $f_{\mathrm{c}}$ increases.

Figure 7 shows the comparison between $V_{\mathrm{u}}$ and $V_{\mathrm{u} \text {,code }}$ predicted by the two different shear formulations of MC2010 [Eqs. (5) and (7)] for elements with fibre only as shear reinforcement. In this figure, specimens were ordered by increasing the residual strength $f_{\mathrm{R}, 3}$. It can be observed that Eq. (5) is characterized by a similar value of $V_{\mathrm{u}} / V_{\mathrm{u} \text {,code }}$ as compared to its base model [Eq. (1)], even if the variability is $15 \%$ greater. To the contrary, Eq. (7) accuracy differs from the one of base model as demonstrated by the mean value of $V_{\mathrm{u}} / V_{\mathrm{u} \text {,code }}$, often smaller than 1 , and by the greater coefficient of variation $(+27 \%)$. Consequently, Eq. (7) leads to more variable and unconservative predictions than Eq. (5). In addition, it should be noticed that both models reduce their level of safety when $f_{\mathrm{R}, 3}$ increases. In fact, for $f_{\mathrm{R}, 3}>3 \mathrm{MPa}$ the ratio $V_{\mathrm{u}} / V_{\mathrm{u} \text {,code }}$ resulted closer or even smaller than 1 as compared to samples with $f_{\mathrm{R}, 3} \leq 3$. This underlines that both models require some modifications in order to better capture the increment of shear strength due to the effect of fibres. The reduction of the ratio $V_{\mathrm{u}} / V_{\mathrm{u} \text {,code }}$ when the effective depth increase is also present as in the base models, even if, for $d$ greater than $1000 \mathrm{~mm}$, Eq. (7) resulted 


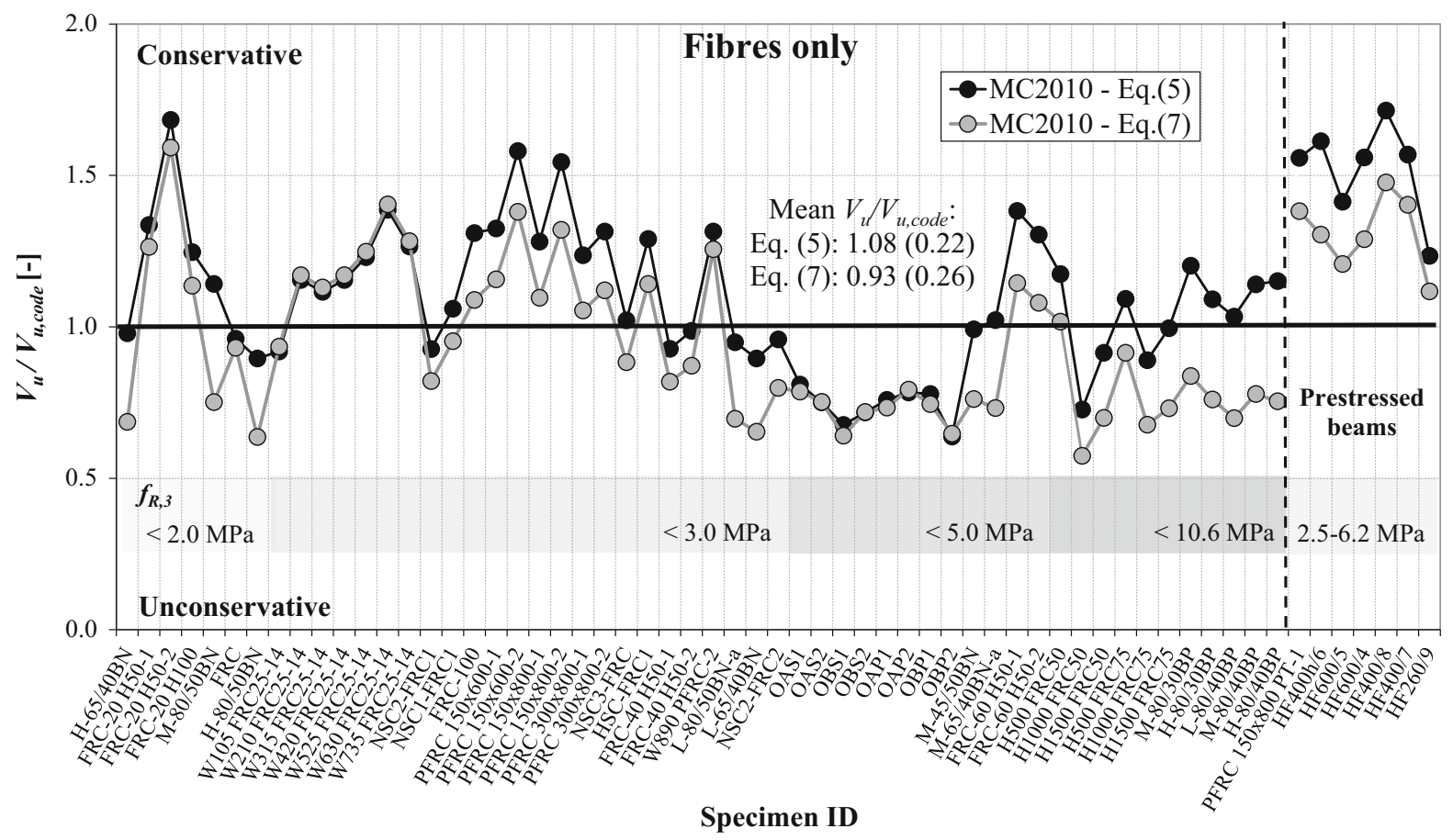

Fig. 7 Comparison against Model Code 2010 shear models for beams reinforced by fibres only

more unconservative than Eq. (5) (see samples H1500 FRC50 and H1500 FRC75 in Fig. 7). Equation (7) led also to more unconservative predictions for $\rho>0.02$ and $f_{\mathrm{c}}>70 \mathrm{MPa}$, while Eq. (5) does not provide significant variation of $V_{\mathrm{u}} / V_{\mathrm{u}, \text { code }}$ with increasing values of $\rho$ or $f_{\mathrm{c}}$. However, it is should be noticed that, in Eq. (5), the shear strength is predicted by imposing a limitation on the longitudinal reinforce-ment ratio as in the base model, i.e. $\rho \leq 0.02$. No influence of $a / d$ was observed in both models.

Figure 8 shows the shear strength predictions of the two models [either Eq. (5) + Eq. (6) with $\theta=45^{\circ}$ or Eq. (7) + Eq. (8)] in case of combination of fibres and web reinforcement. It can be observed that both models resulted comparable and always unconservative; the mean value of $V_{\mathrm{u}} / V_{\mathrm{u} \text {,code }}$ was of around 0.88 with a low $\mathrm{CV}$. This evidence underlines that both models probably require modifications for improve their predictions in case of elements reinforced by both fibres and web reinforcement. However, since the available data concerning beams reinforced by both fibres and stirrups are limited (10 samples), further specific experiments should be carried out in order to confirm this model inadequacy.

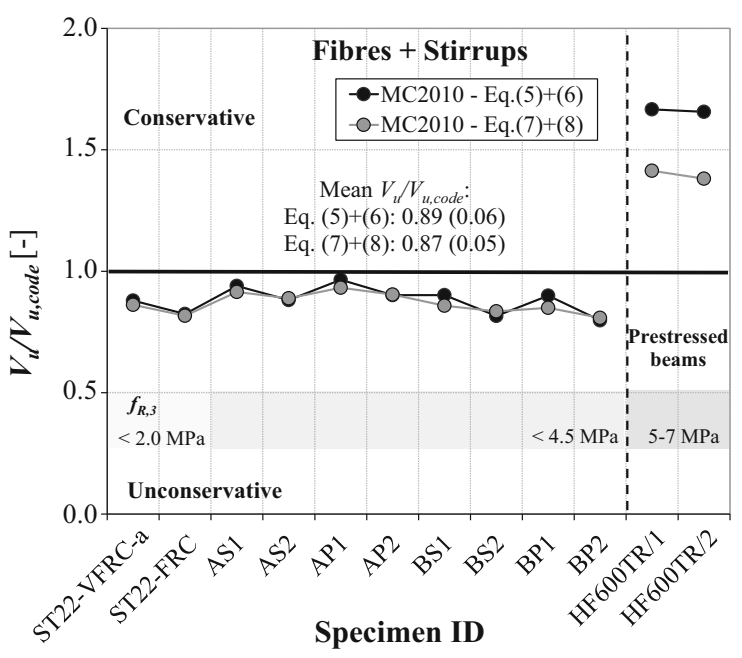

Fig. 8 Comparison against Model Code 2010 shear models for beams reinforced by both fibres and web reinforcement

Finally, it can be underlined that, in case of prestressed elements, the equations listed in Table 3 are always conservative both in RC (Figs. 5, 6) and FRC elements (Figs. 7, 8). However, it should be reminded that only few prestressed specimens are 
available and the majority of them showed a webshear failure.

\section{Concluding remarks}

Experimental tests on RC and FRC elements carried out in the last decade at both the University of Brescia and the Universitat Politècnica de València were collected and analysed in the present paper. The following conclusions might be drawn:

(1) A comprehensive shear database of 171 elements (93 in FRC and their related 78 reference samples in RC with or without web reinforcement) is presented, defining the principal variables $\left(d, a / d, \rho, \rho_{\mathrm{w}}, f_{\mathrm{c}}, d_{\mathrm{g}}, \sigma_{\mathrm{p}}\right)$ and the residual mechanical properties of FRC: $f_{\mathrm{R}, 1}$ and $f_{\mathrm{R}, 3}$. This database will allow further development and validation of suitable shear strength formulations for FRC elements;

(2) $\quad a / d, \rho$, and $f_{\mathrm{c}}$ (related to tensile strength) similarly influence the shear strength both in RC and FRC elements. Instead, the beam size influence is different for $d>1000 \mathrm{~mm}$ since the horizontal asymptote is reached earlier in FRC members (for $d \leq 1000 \mathrm{~mm}$ classical RC size effect law can be applied also for FRC elements);

(3) EC2 and MC2010 shear formulations lead to similar and good predictions of the shear resistance of RC elements with or without web reinforcement;

(4) The two shear models provided by MC2010 ( $f_{\mathrm{Ftu}}$ evaluated in both models according to MC2010 linear model, even if direct tensile tests are suggested by MC2010 for Eq. (7)) for elements reinforced by fibre only reduce their level of safety when $f_{\mathrm{R}, 3}$ increases. In fact, for $f_{\mathrm{R}, 3}>3$ MPa the model safety factor $\left(V_{\mathrm{u}} / V_{\mathrm{u}, \text { code }}\right)$ resulted closer or even smaller than 1 , as compared to samples with $f_{\mathrm{R}, 3} \leq 3$;

(5) The FRC shear strength equation of MC2010 based on EC2 model (Eq. 5 in Table 3) resulted more conservative than the one developed on the Modified Compression Field Theory (Eq. 7 in Table 3 with the assumption of evaluating $f_{\mathrm{Ftu}}$ from the MC2010 linear model). In partic-ular, they mainly differ for specimens with $d>1000$ $\mathrm{mm}, \rho>0.02$ and $f_{\mathrm{c}}>70 \mathrm{MPa}$.
(6) The shear strength of elements reinforced by a combination of fibres and web reinforcement seems not to be well predicted by MC2010.

The Authors would like also to encourage all researchers to provide in their future works at least the information reported in the database in order to allow its extension. The results of FRC characterization tests are, with this respect, very important and needful.

\section{Compliance with ethical standards}

Conflict of interest The authors declare that they have no conflict of interest.

\section{References}

1. Imam M, Vandewalle L, Mortelmans F, Gemert VD (1997) Shear domain of fibre-reinforced high-strength concrete beams. Eng Struct 19:738-747

2. Di Prisco M, Plizzari GA, Vandewalle L (2010) Shear and punching shear in RC and FRC elements. In: fib Bulletin 57

3. Dinh HH, Parra-Montesinos GJ, Wight J (2010) Shear behaviour of steel fibre-reinforced concrete beams without stirrup reinforcement. ACI Struct J 107:597-606

4. Cucchiara C, La Mendola L, Papia M (2004) Effectiveness of stirrups and steel fibers as shear reinforcement. Cement Concr Compos 26:777-786

5. Kovács I, Balázs GL (2003) Structural behavior of steel fiber reinforced concrete. J Struct Concr 4:57-63

6. Shoaib A, Lubell AS, Bindiganavile VS (2014) Size effect in shear for steel-fiber-reinforced concrete members without stirrups. ACI Struct J 111:1081-1090

7. Altoubat S, Yazdanbakhsh A, Rieder KA (2009) Shear behavior of macro-synthetic fiber-reinforced concrete beams without stirrups. ACI Mater J 106:38-389

8. Soetens T, Matthys S, Hertelé S, De Waele W (2017) Shear behavior of prestressed precast SFRC girders. Eng Struct 142:20-35

9. Conforti A, Minelli F (2016) Compression field modelling of fibre reinforced concrete shear critical deep beams: a numerical study. Mater Struct 49(8):3369-3383

10. Ding Y, You Z, Jalali S (2011) The composite effect of steel fibres and stirrups on the shear behaviour of beams using self-consolidating concrete. Eng Struct 33:107-117

11. Cuenca E, Echegaray-Oviedo J, Serna P (2015) Influence of concrete matrix and type of fiber on the shear behavior of self-compacting fiber reinforced concrete beams. Compos B Eng 75:135-147

12. Cuenca E, Serna P (2013) Failure modes and shear design of prestressed hollow core slabs made of fiber-reinforced concrete. Compos B Eng 45:952-964

13. RILEM TC 162-TDF (2003) Test and design methods for steel fiber reinforced concrete: $\sigma$ - $\varepsilon$-design method. Final recommendation. Mater Struct 36:560-567

14. Federation Internationale du Beton (fib) (2012) Model Code 2010-final draft, Vol. 1, Bulletin 65 and Vol. 2, Bulletin 66. Lausanne 
15. American Concrete Institute (2014) Building code requirements for structural concrete (ACI 318-14) and commentary. American Concrete Institute, Detroit

16. EN 14651 (2005) Test method for metallic fibre concrete. Measuring the flexural tensile strength (limit of proportionality (LOP), residual). British Standards Institution, London

17. Amin A, Foster SJ, Muttoni A (2015) Derivation of the $\sigma$-w relationship for SFRC from prism bending tests. Struct Concr 16(1):93-105

18. Conforti A, Minelli F, Plizzari G, Tiberti G (2017) Comparing test methods for the mechanical characterization of fiber reinforced concrete. Struct Concr. https://doi.org/10. 1002/suco.201700057

19. Yazdanbakhsh A, Altoubat S, Rieder KA (2015) Analytical study on shear strength of macro synthetic fiber reinforced concrete beams. Eng Struct 100:622-632

20. Kim SK, Lee SH, Hwang JH, Kuchma DA (2012) Shear behavior model for steel fiber-reinforced concrete members without transverse reinforcement. Compos B Eng 43:2324-2334

21. Parra-Montesinos GJ (2006) Shear strength of beams with deformed steel fibers. Concr Int 28:57-66

22. Zhang F, Ding Y, Xu J, Zhang Y, Zhu W, Shi Y (2016) Shear strength prediction for steel fiber reinforced concrete beams without stirrups. Eng Struct 127:101-116

23. Voo YN, Poon WK, Foster SJ (2010) Shear strength of steel fiber-reinforced ultrahigh-performance concrete beams without stirrups. J Struct Eng 136:1393-1400

24. Amin A, Foster SJ (2016) Shear strength of steel fibre reinforced concrete beams with stirrups. Eng Struct 111:323-332

25. Reineck KH, Kuchma DA, Kim KS, Marx S (2003) Shear database for reinforced concrete members without shear reinforcement. ACI Struct J 100:240-249

26. Reineck KH, Bentz EC, Fitik B, Kuchma DA, Bayrak O (2013) ACI-DAfStb database of shear tests on slender reinforced concrete beams without stirrups. ACI Struct J 110:867-876

27. European Committee for Standardization (2004) Eurocode 2: design of concrete structures-Part 1-1: general rules and rules for buildings. Final Draft, prEN 1992-1-1, Brussels

28. Minelli F, Plizzari GA (2013) On the effectiveness of steel fibers as shear reinforcement. ACI Struct J 110(3):379-389

29. Bertozzi A, Reggia A (2006) Fibre di acciaio per l'armatura minima a taglio delle travi (in Italian). MS thesis. University of Brescia, Brescia

30. Minelli F, Plizzari GA, Vecchio FJ (2007) Influence of steel fibers on full-scale RC beams under shear loading. In: Proceedings of the international conference FraMCoS-high performance concrete, Brick-Masonry and environmental aspects. Catania, Italy

31. Conforti A (2008) Il traliccio ad inclinazione variabile per il progetto a taglio di travi fibrorinforzate: studio sperimentale e analitico (in Italian). MS thesis. University of Brescia, Brescia

32. Minelli F, Conforti A, Cuenca E, Plizzari G (2014) Are steel fibres able to mitigate or eliminate size effect in shear. Mater Struct 47(3):459-473

33. Conforti A, Minelli F, Tinini A, Plizzari GA, Moro S (2014) Structural applicability of polypropylene fibres: deep and wide-shallow beams subjected to shear. ACI Spec Publ 310:171-180

34. Conforti A, Minelli F, Plizzari GA (2013) Wide-shallow beams with and without steel fibres: a peculiar behaviour in shear and flexure. Compos B Eng 51:282-290

35. Conforti A, Minelli F, Tinini A, Plizzari GA (2015) Influence of polypropylene fibre reinforcement and width-toeffective depth ratio in wide-shallow beams. Eng Struct $88: 12-21$

36. Conforti A, Minelli F, Plizzari GA (2017) Influence of width-to-effective depth ratio on shear strength of RC elements without web reinforcement. ACI Struct J 114(4):995-1006. https://doi.org/10.14359/51689681

37. Cuenca E (2015) On shear behavior of structural elements made of steel fiber reinforced concrete. Ph.D. dissertation. Springer Thesis. Springer International Publishing, Switzerland

38. Cuenca E, Serna P (2013) Shear behavior of prestressed precast beams made of self-compacting fiber reinforced concrete. Constr Build Mater 45:145-156

39. Ortiz-Navas F, Navarro-Gregori J, Leiva-Herdocia GE, Serna-Ros P, Cuenca E (2018) An experimental study on the shear behaviour of reinforced concrete beams including macro-synthetic fibres. Constr Build Mater (in press)

40. Barr BIG, Lee MK, Hansen P, Dupont D, Erdem E, Schaerlaekens S, Schnutgen B, Stand H, Vandewalle L (2003) Round-Robin analysis of the RILEM TC 162-TDF beam-bending test: Part 1-test method evaluation. Mater Struct 36:609-620

41. Stähli P, Custer R, van Mier JGM (2008) On flow properties, fibre distribution, fibre orientation and flexural behaviour of FRC. Mater Struct 41:189-196

42. Barragán B, Gettu R, Agulló L, Zerbino R (2006) Shear failure of steel fiber-reinforced concrete based on push-off tests. ACI Mater J 103(4):251-257

43. Echegaray-Oviedo J, Navarro-Gregori J, Cuenca E, Serna P (2017) Modified push-off test for analysing the shear behaviour of concrete cracks. Strain 53(6):e12239. https:// doi.org/10.1111/str.12239

44. Echegaray-Oviedo J, Navarro-Gregori J, Cuenca E, Serna P (2013) Upgrading the push-off test to study the mechanisms of shear transfer in FRC elements. In: Proceedings of the 8th international conference on fracture mechanics of concrete and concrete structures (FraMCoS), pp 1012-1021

45. Minelli F, Plizzari GA (2008) Shear design of FRC members with little or no conventional shear reinforcement. In: Proceedings of the international FIB symposium 2008tailor made concrete structures: new solutions for our society, Amsterdam, Netherlands

46. Voo JYL, Foster SJ (2003) Variable engagement model for fibre-reinforced concrete in tension. UNICIV report R-420. School of Civil and Environmental Engineering, The University of New South Wales, Sidney. ISBN: 858413876

47. Bentz EC, Vecchio FJ, Collins MP (2006) The simplified MCFT for calculating the shear strength of reinforced concrete elements. ACI Struct J 103:614-624

48. Foster SJ, Agarwal A, Amin A (2017) Design of steel fiber reinforced concrete beams for shear using inverse analysis for determination of residual tensile strength. Struct Concr. https://doi.org/10.1002/suco.201700100 